\title{
PENINGKATAN KINERJA REPRODUKSI, KUALITAS TELUR, DAN LARVA MELALUI SUPLEMENTASI Spirulina DIKOMBINASI DENGAN INJEKSI OOCYTE DEVELOPER PADA INDUK IKAN LELE (Clarias Sp.) BETINA
}

\author{
Armen Nainggolan", Agus Oman Sudrajat, Nur Bambang Priyo Utomo, dan Enang Harris \\ Program Studi IImu Akuakultur, Sekolah Pascasarjana, Institut Pertanian Bogor
}

(Naskah diterima: 20 Oktober 2014; Revisi final: 23 Maret 2015, Disetujui publikasi: 5 Juni 2015)

\begin{abstract}
ABSTRAK
Penelitian ini dilakukan untuk mempercepat maturasi, meningkatkan kualitas telur, dan kuantitas larva ikan lele (Clarias sp.) melalui pemberian kombinasi suplementasi Spirulina pada pakan dan penyuntikan Oocyte developer (Oodev). Perlakuan yang diberikan terdiri atas: pakan $\mathrm{A}_{1}$ : Spirulina 0\%dengan Oodev 0 IU; pakan $\mathrm{A}_{2}$ : Spirulina 0\%dengan Oodev $15 \mathrm{IU}$; pakan $\mathrm{B}_{1}$ : Spirulina 1\%dengan Oodev $0 \mathrm{IU}$; pakan $\mathrm{B}_{2}$ : Spirulina 1\%dengan Oodev 15 IU; pakan $\mathrm{C}_{1}$ : Spirulina 2\%dengan Oodev 0 IU; pakan $\mathrm{C}_{2}$ : Spirulina 2\%dengan Oodev 15 IU; pakan $\mathrm{D}_{1}$ : Spirulina 3\%dengan Oodev 0 IU; pakan $\mathrm{D}_{2}$ : Spirulina 3\%dengan Oodev $15 \mathrm{IU}$. Selama 30 hari pemeliharaan, induk ikan diberi pakan perlakuan dengan feeding rate sebesar $3 \%$ dari bobot badannya dengan frekuensi pemberian dua kali sehari pada pukul 8.00 dan 17.00 WIB. Parameter yang diamati adalah Gonado Somatic Index (GSI), konsentrasi estradiol-17 $\beta$, konsentrasi protein vitelogenin, fekunditas dan viabilitas larva. Hasil penelitian menunjukkan bahwa nilai GSI tertinggi selama penelitian diperoleh pada perlakuan $D_{2}(9,94 \%)$ dibandingkan dengan perlakuan yang lain. Hasil analisis estradiol-17 $\beta$ dan vitelogenin pada perlakuan $D_{2}$ mengindikasikan kematangan gonad lebih cepat dibandingkan dengan perlakuan yang lain. Selanjutnya fekunditas tertinggi dihasilkan pada perlakuan $\mathrm{D}_{2}$ sebesar $81.953 \pm 164$ butir dengan derajat penetasan $90,70 \pm 0,24$ dan sintasan larva tertinggi (umur empat hari) yakni sebesar $92,94 \pm 0,064$. Dengan demikian, suplementasi Spirulina dengan dosis 3\%pada pakan yang dikombinasikan dengan Oodev dosis 15 IU adalah yang terbaik untuk mempercepat kematangan gonad induk dan menstimulasi kinerja reproduksi terutama pada perkembangan gonad, kualitas telur, larva, dan ketahanan hidup larva.
\end{abstract}

KATA KUNCl: induk ikan lele, kinerja reproduksi, kualitas telur, kualitas larva, Spirulina, Oodev

ABSTRACT: Improving reproduction performance, egg and larvae quality by combination of dietary Spirulina supplementation and oocyte developer injection to female catfish (Clarias sp.) broodstock. By: Armen Nainggolan, Agus Oman Sudrajat, Nur Bambang Priyo Utomo, and Enang Harris

The research was performed to accelerate maturation and increase the egg and larvae quantity of catfish (Clarias sp.) by combination of dietary Spirulina and Oocyte developer (Oodev) administration. The treatments were feed $A_{1}$ : Spirulina 0\%combined with Oodev 0 IU; feed $A_{2}$ : Spirulina 0\% combined with Oodev 15 IU; feed $B_{1}$ : Spirulina $1 \%$ combined with Oodev $0 \mathrm{IU}$; feed $\mathrm{B}_{2}$ : Spirulina 1\%combined with Oodev $15 \mathrm{IU}$; feed $\mathrm{C}_{1}$ : Spirulina 2\%combined with Oodev 0 IU; feed $\mathrm{C}_{2}$ : Spirulina 2\%combined with Oodev $15 \mathrm{IU}$; feed $\mathrm{D}_{1}$ : Spirulina 3\%combined with Oodev 0 IU; feed $D_{2}$ : Spirulina 3\%combined with Oodev $15 \mathrm{IU}$. Each treatment used 10 fishs as replication. During the experiment (30 days), female catfish broodstock were fed treatment diet with feeding rate of $3 \%$ of the body weight twice daily at 8:00 am and 17:00 pm. The observed parameters were Gonado Somatic Index (GSI), the profile of estradiol-17 $\beta$, vitellogenin protein concentration, fecundity, and larvae viability. The results showed that the profile of estradiol-17 $\beta$ and vitellogenin in the treatment $D_{2}$ indicated gonad maturity faster than with other treatments. Furthermore, the $D_{2}$ fish treatment produced $81,953 \pm 164$ eggs, hatching rate of $90.70 \pm 0.24$ and $92.94 \pm 0.064$ survival rate of four days larvae old. This treatments higher than with other treatments. Thus, the combination of Spirulina 3\%and 15 IU Oodev could accelerate oocyte growth and increase the viability of eggs and larvae.

KEYWORDS: catfish (Clarias sp.) broodstock, reproduction performance, egg quality, larvae quality, Spirulina, Oodev

\# Korespondensi: Program Studi Ilmu Akuakultur, Sekolah

Pascasarjana, Institut Pertanian Bogor. JI. Agatis, Kampus IPB

Darmaga, Bogor 16680, Indonesia.

E-mail: omanipb@yahoo.com 


\section{PENDAHULUAN}

Ikan lele (Clarias sp.) memiliki nilai ekonomis yang tinggi. Nilai produksi ikan ini selalu mengalami peningkatan, tetapi tidak selalu diiringi dengan peningkatan kualitas dan kuantitas sesuai yang diinginkan pasar domestik dan internasional. Oleh karena itu, salah satu usaha yang mutlak dibutuhkan untuk mengembangkannya adalah penyediaan benih bermutu yang memiliki produktivitas budidaya tinggi, berkelanjutan, dan tepat waktu. Untuk mewujudkannya, ketersediaan induk yang berkualitas merupakan faktor penentu dalam keberhasilan kegiatan tersebut.

Salah satu cara untuk memperoleh hasil pembenihan ikan yang optimal yaitu dengan memperbaiki performa/kinerja reproduksi melalui suplementasi nutrien pada pakan induk yang dikombinasikan dengan premiks hormon untuk mempercepat reproduksi dan tidak bergantung musim. Hasil penelitian Rahmatia (2013) bahwa penambahan Spirulina platensis pada pakan yang dikombinasikan dengan oocyte developer (Oodev) pada induk ikan nila memperlihatkan peningkatan kinerja reproduksi. Oodev tersebut mengandung Pregnant Mare Serum Gonadotropin dan anti-dopamine (PMSG + ad). Prinsip dan fungsi penggunaan premiks hormon adalah untuk merangsang terjadinya lonjakan kadar Gonadotropin Releasing Hormon (GnRH) yang selanjutnya akan memengaruhi kelenjar pituitari untuk memproduksi gonadotropin. Setelah itu, gonadotropin akan merangsang ovari untuk proses pematangan telur pada ikan (Bolamba et al., 1992). Pada ikan lele dumbo (Clarias gariepinus) misalnya untuk memproduksi skala massal, pemijahan induk dilakukan dengan menggunakan kombinasi hormon PMSG dengan hCG (Zairin et al., 1992). Selain itu, penyuntikan Oodev $20 \mathrm{IU}$ pada ikan patin dapat mempercepat pematangan gonad awal atau vitelogenesis (Rafiuddin, 2013).

Watanabe et al. (1984) menyatakan bahwa induk ikan red sea bream diberi pakan yang kurang mengandung asam lemak esensial akan menghasilkan telur yang derajat penetasannya rendah dan sebagian besar dari larva yang dihasilkannya adalah abnormal. Spirulina merupakan salah satu jenis mikroalga yang baik digunakan sebagai suplemen pakan induk ikan yang berkualitas untuk pemenuhan performa dan kualitas reproduksi induk ikan lele. Kandungan nutrisi Spirulina cukup tinggi, yakni kandungan protein $60 \% 70 \%$ vitamin (B1, B2, tokoferol), asam amino esensial, mineral, dan asam lemak esensial seperti asam gamma-linolenat (GLA) (Diraman et al., 2009). Penelitian mengenai Spirulina sebagai pakan suplemen pada ikan patin (Pangasius bocourti) dan ikan nila (Oreochromis niloticus) dilaporkan dapat meningkatkan performa reproduksi dan sintasan, dibandingkan dengan pakan ikan konvensional (Meng-Umphan, 2009; Lu \& Takeuchi, 2004;
Jongkon \& Chanagun, 2011). Bahkan hasil penelitian Xiao -ying et al. (2009) menyatakan bahwa asam lemak esensial seperti GLA yang dikandung Spirulina dapat merangsang produksi prostaglandin yang mengatur pertumbuhan dan fungsi hati dan darah, serta vitamin yang dikandung Spirulina merupakan sumber antioksidan dan mencegah bahaya radikal bebas. Selain itu, penambahan Spirulina platensis 1,5\%dan 3\%pada pakan induk ikan lele dapat meningkatkan fekunditas dan sintasan larva (Mayasari, 2012).

Berdasarkan pertimbangan pemanfaatan kualitas nutrisi dan hormonal, maka penelitian ini menggunakan Spirulina yang ditambahkan pada pakan dan dikombinasikan dengan Oodev. Penggunaan hormon ini dimaksudkan untuk mempercepat maturasi induk lele, sedangkan suplementasi nutrisi Spirulina adalah untuk meningkatkan kualitas telur dan larva ikan lele. Oleh karenanya perlu dilakukan penelitian untuk mengevaluasi penambahan Spirulina dalam pakan yang dikombinasikan dengan penyuntikan Oodev untuk melihat pengaruhnya terhadap peningkatan mutu reproduksi seperti: pematangan gonad, kualitas telur, dan ketahanan hidup larva ikan lele.

\section{BAHAN DAN METODE}

\section{Waktu dan Tempat Penelitian}

Penelitian ini dilaksanakan mulai bulan Oktober 2012 sampai dengan Agustus 2013 dan merupakan bagian dari penelitian disertasi. Pemeliharaan induk ikan, pemberian pakan uji, perlakuan penyuntikan Oodev dan ovaprim, sampling ikan, serta penetasan larva dilakukan di kolam pemeliharaan dan Laboratorium Budidaya/Pengembangbiakan Aquatik SEAMEOBIOTROP Tajur, Bogor. Pembuatan pakan uji dilakukan di Laboratorium Nutrisi Ikan Departemen Budidaya Perairan, Fakultas Perikanan dan IImu Kelautan, Institut Pertanian Bogor (IPB). Analisis asam lemak dilakukan di Laboratorium Kimia Terpadu IPB. Analisis estradiol-17 $\beta$ dilakukan di Laboratorium Fisiologi, Fakultas Kedokteran Hewan IPB, dan analisis vitelogenin dilakukan di Laboratorium Pusat Antar Universitas (PAU) IPB.

\section{Ikan Uji}

Ikan uji yang digunakan adalah induk ikan lele (Clarias sp.) berumur sekitar 12 bulan yang diperoleh dari Balai Besar Pengembangan Budidaya Air Tawar (BBPBAT) Sukabumi, Jawa Barat. Induk betina mempunyai bobot berkisar antara 500-525 g/ekor dengan panjang total $30-35 \mathrm{~cm}$. Induk jantan mempunyai bobot 800-1.200 g/ekor dengan panjang $40-45 \mathrm{~cm}$. Pada percobaan ini digunakan sebanyak 80 ekor induk betina dan 40 ekor induk jantan. 


\section{Pakan Uji dan Hormon}

Pakan uji dibuat dengan mencampurkan tepung Spirulina sesuai dosis perlakuan $(0 \%$ 1\% 2\% dan 3\% pada pelet komersial yang telah ditepung ulang. Campuran adonan ini selanjutnya dicetak kembali menjadi pelet kering untuk percobaan. Penambahan mikroalga ini sudah dalam bentuk tepung yang diperoleh dari PT Polaris Indonesia. Selama pemeliharaan induk lele diberi pakan perlakuan sebesar 3\%dari bobot badannya. Frekuensi pemberian pakan sebanyak dua kali sehari yakni pukul 8.00 dan 17.00 WIB. Kandungan asam lemak pakan uji dianalisis menggunakan Gas Liquid Chromatography (GLC) dengan silica capillary column (GC-15A, Shimadzu Corp., Japan).

Hormon yang digunakan dalam pengujian ini adalah premiks Oocyte developer (Oodev) yang merupakan produk yang dikembangkan oleh Labo ratorium Reproduksi dan Genetika Organisme Akuatik, Departemen Budidaya Perairan, IPB. Oodev mengandung Pregnant Mare Serum Gonadotropin (PMSG) + Antidopamine. Selain itu, juga digunakan hormon Luteinizing-hormonereleasing hormone $(\mathrm{LHRH})+$ Antidopamine (Ovaprim, produk dari Syndel Canada) untuk merangsang ovulasi (pemijahan) ikan.

\section{Rancangan Perlakuan}

Rancangan perlakuan dari penelitian ini adalah rancangan acak lengkap faktorial. Perlakuan yang diujicobakan dalam penelitian ini sebanyak delapan perlakuan yang merupakan kombinasi dosis Spirulina dan dosis Oodev. Dosis Spirulina sebanyak empat dosis yang berbeda dalam pakan ikan, yaitu: $0 \% 1 \% 2 \%$ dan $3 \%$ sedangkan dosis Oodev yang diujicobakan sebanyak dua dosis, masing-masing sebesar 0 IU dan $15 \mathrm{IU}$. Oodev disuntikkan pada bagian belakang sirip punggung ikan secara intramuskuler dengan interval waktu antar penyuntikan 10 hari sebanyak tiga kali, yaitu: pada hari ke-0, hari ke-10, dan hari ke-20. Penyuntikan selanjutnya dilakukan secara intramuskuler dengan menggunakan Ovaprim dengan dosis $0,5 \mathrm{~mL} / \mathrm{kg}$ ikan pada hari ke-31 untuk merangsang ovulasi (pemijahan) ikan. Sepuluh jam setelah penyuntikan Ovaprin, telur dikeluarkan dengan cara pengurutan (stripping). Telur yang diperoleh ditampung dalam baskom kecil, kemudian diberi larutan fisiologis sebanyak $1 \mathrm{~mL}$, dan selanjutnya ditambahkan sperma dari ikan jantan, diaduk sampai rata, dan dimasukkan air untuk mengaktifkan sperma supaya terjadi pembuahan. Selanjutnya telur dipindahkan ke dalam akuarium untuk diinkubasi. Perkembangan telur diamati sampai dengan menetas menjadi larva. Untuk mendapatkan sperma, induk jantan dibedah, diambil gonadnya, digunting, dan sperma dimasukkan dalam larutan fisiologis 0,5 $\mathrm{mL}$.
Setiap perlakuan menggunakan satu wadah bak beton dan tiap wadah diisi sepuluh ekor induk ikan. Satu ekor induk ikan diambil setiap sepuluh hari sampai total empat ekor dari setiap perlakuan untuk pengamatan estradiol-17 $\beta$, vitelogenin, histologi gonad, serta analisis gonado somatic index (GSI). Sebanyak enam ekor ikan lainnya digunakan untuk pengamatan performa reproduksi pada akhir penelitian.

\section{Parameter Uji dan Analisis Statistik}

Peubah yang diamati dalam penelitian ini adalah sebagai berikut:

\section{Kadar Hormon Estradiol-17 $\beta$}

Pengukuran konsentrasi estradiol-17 $\beta$ dalam plasma darah induk ikan lele dilakukan dengan metode ELISA (DRG Instruments GmbH) (Germany, 2010). Konsentrasi estradiol-17 $\beta$ dalam plasma darah diukur setiap sepuluh hari dari awal hingga akhir pemeliharaan (hari ke-0, 10, 20, dan ke-30).

\section{Vitelogenin (Vtg)}

Pengukuran konsentrasi vitelogenin plasma darah ikan diawali dengan pengukuran plasma darah ikan melalui elektroforesis pada gel poliakrilamide (Sodium Dodecyl Sulphate Polyacrylamide Gel Electroforesis: SDS-PAGE). Hasil analisis SDS-PAGE berupa gel tersebut dimasukkan ke dalam program software Total Lab TL120 (www.totallab.com, 2013). Setelah masuk ke dalam program tersebut, secara otomatis akan menghasilkan data kuantifikasi per sampel secara menyeluruh. Selanjutnya, konsentrasi protein diukur dengan metode Bradford (1976) dalam Bollag \& Edelstain (1991) yakni: sebanyak $100 \mu \mathrm{L}$ contoh ditambah dengan $1 \mathrm{~mL}$ pereaksi Bradford kemudian dihomogenasi dengan vortex dan absorbansi diukur pada panjang gelombang $595 \mathrm{~nm}$. Pereaksi Bradford berasal dari larutan stok yakni: $100 \mathrm{~mL}$ etanol $95 \% 200$ $\mathrm{mL}$ phosphoric acid 88\%dan $350 \mathrm{mg}$ Serva blue G. Sebanyak $30 \mathrm{~mL}$ larutan stok ditambah $425 \mathrm{~mL}$ akuades, $15 \mathrm{~mL}$ etanol 95\%dan $30 \mathrm{~mL}$ phosphoric acid $88 \%$ Campuran tersebut diencerkan dua kali sebelum digunakan untuk analisis protein. Konsentrasi protein contoh dihitung berdasarkan kurva standar yang dibuat dari Bovine Serum Albumin (BSA). Khusus pada tahap pemurnian, protein dimonitor dengan cara mengukur serapan pada panjang gelombang $280 \mathrm{~nm}\left(\mathrm{~A}_{280}\right)$.

Hasil pengukuran protein berdasarkan metode di atas dikalikan dengan hasil kuantifikasi dari software Total Lab TL120 yang sebelumnya telah dibagikan dengan nilai kuantifikasi per analisis.

\section{Gonado Somatic Index (GSI)}

GSI dihitung dengan menggunakan rumus: 


$$
\text { GSI }(\%)=\frac{\text { Bobot ovarium }}{\text { Bobot badan ikan }} \times 100 \%
$$

\section{Analisis Kandungan Asam Lemak}

Analisis kandungan asam lemak telur dan larva dari delapan perlakuan dilakukan menggunakan GLC dengan silica capillary column (GC-15A, Shimadzu Corp., Japan) dengan metode analisis AOAC International (1984) butir 28.060/GC.

\section{Fekunditas}

Fekunditas (F) dihitung dengan menggunakan rumus sebagai berikut:

$$
\mathrm{F} \text { (butir/g induk) }=\frac{\text { Jumlah telur yang diovulasi }}{\text { Bobot induk }(\mathrm{g})}
$$

\section{Derajat Tetas Telur}

Perhitungan derajat tetas telur (HR) menggunakan rumus sebagai berikut:

$$
H R(\%)=\frac{\text { Jumlah telur yang menetas }}{\text { Jumlah telur yang ditetaskan }} \times 100 \%
$$

\section{Sintasan Larva}

Sintasan larva (SR) dihitung mulai dari hari ke-0 (hari pertama telur menetas) hingga hari ke-4 dengan menggunakan rumus:

$$
\text { SR }(\%)=\frac{\text { Jumlah larva akhir pemeliharaan }}{\text { Jumlah larva awal pemeliharaan }} \times 100 \%
$$

\section{Analisis Data}

Data hasil pengamatan konsentrasi hormon estradiol-17 $\beta$, konsentrasi vitelogenin, dan GSI ditampilkan secara deskriptif dalam bentuk grafik dan gambar. Fekunditas, derajat tetas telur, dan sintasan larva dilakukan analisis sidik ragam (ANOVA) dan uji lanjut $(P<0,05)$ menggunakan uji Duncan dengan SPSS 16.0.

\section{HASIL DAN BAHASAN}

\section{Hasil}

\section{Pakan Uji}

Pakan yang telah ditambahkan Spirulina dengan dosis yang berbeda dianalisis asam lemaknya. Berdasarkan hasil analisis bahwa peningkatan jumlah asam lemak pada pakan perlakuan meningkat seiring dengan peningkatan penambahan persentase Spirulina (Tabel 1). Jumlah asam lemak n-6 tertinggi diperoleh pada pakan perlakuan D (Spirulina 3\% yakni sebesar 0,23\% dan terendah pada pakan perlakuan A (Spirulina 0\%) sebesar 0,15\% Selanjutnya, jumlah asam lemak esensial $n-3$ tertinggi pada perlakuan C (Spirulina 2\% dan D (Spirulina 3\%) yakni sebesar 2,08\% dan 2,06\% dan terendah pada pakan perlakuan A (Spirulina $0 \%$ sebesar 1,55\%(Tabel 1 ).

\section{Kadar Estradiol-17 $\beta$ dalam Darah Induk Lele}

Nilai rataan konsentrasi estradiol-17 $\beta$ pada semua perlakuan (perlakuan Al sampai dengan perlakuan D2) pada hari ke-0 (awal) semuanya sama yakni 1,12 $\mathrm{ng} / \mathrm{mL}$ (Gambar 1). Kemudian seiring dengan perkembangan gonad, pada hari ke-10 konsentrasi estradiol$17 \beta$ mengalami peningkatan, yakni berkisar dari 1,65 $\mathrm{ng} / \mathrm{mL}$ pada perlakuan Al sampai dengan $5,38 \mathrm{ng} / \mathrm{mL}$ pada perlakuan D2 dan pada hari ke-20 mengalami penurunan menjadi $1,61 \mathrm{ng} / \mathrm{mL}$ pada perlakuan $\mathrm{A} 1$ sampai dengan $1,87 \mathrm{ng} / \mathrm{mL}$ pada perlakuan D2. Selanjutnya pada hari ke-30, juga mengalami penurunan yakni sebesar $1,01 \mathrm{ng} / \mathrm{mL}$ pada perlakuan Al sampai dengan $0,53 \mathrm{ng} / \mathrm{mL}$ pada perlakuan D2. Meskipun demikian, kecepatan penurunan konsentrasi estradiol$17 \beta$ pada semua perlakuan berbeda-beda. Kecepatan penurunan menggambarkan kematangan gonad lebih awal.

Hasil pengamatan secara keseluruhan konsentrasi estradiol-17 $\beta$ menunjukkan bahwa induksi hormon (Oodev) dapat mempercepat proses maturasi dibanding tanpa Oodev. Selain itu, bila dibandingkan dengan kontrol (perlakuan A1), penambahan Spirulina mampu meningkatkan konsentrasi estradiol-17 $\beta$.

\section{Profil Vitelogenin (Vtg)}

Hasil elektroforesis menunjukkan bahwa vitelogenin dapat terdeteksi pada plasma induk ikan lele betina yang bertelur pada semua perlakuan dengan bobot molekul 200 kDa (Gambar 2). Pengukuran vitelogenin pada ikan betina sebelum memperoleh perlakuan tidak menunjukkan keberadaan vitelogenin dengan bobot molekul 200 kDa. Periode awal vitelogenesis dapat ditunjukkan dengan permulaan terdeteksinya vitelogenin dalam darah. Gambar 3 menunjukkan periode awal vitelogenesis dari tiap-tiap perlakuan yang ditandai dengan diperolehnya konsentrasi vitelogenin pada hari yang berbeda.

Gambar 3 menunjukkan bahwa proses vitelogenesis berlangsung dengan cepat, di mana pada hari ke-10 untuk semua perlakuan merupakan nilai tertinggi selama masa percobaan, kemudian seiring dengan perkembangan gonad, konsentrasi tersebut mengalami penurunan pada hari ke-20 sampai hari ke-30 pada semua perlakuan. Namun demikian, bila dibandingkan dengan perlakuan $A 1$, periode vitelogenesis lebih cepat terjadi dengan adanya perlakuan suplementasi Spirulina, penyuntikan Oodev, dan kombinasi keduanya. Nilai konsentrasi vitelogenin hasil analisis selama percobaan berkisar dari $0,05 \mathrm{~g} / \mathrm{mL}$ pada perlakuan Al sampai dengan $0,15 \mathrm{~g} / \mathrm{mL}$ perla- 
Tabel 1. Proksimat (\%bobot kering), asam lemak n-6 dan n-3 (\%dari total lemak) pakan yang disuplementasi S. platensis pada berbagai dosis

Table 1. Proximate (\%dry weight), n-6 and n-3 fatty acids (\% of total fat) in feed supplemented with Spirulina at various doses

\begin{tabular}{lcccc}
\hline & \multicolumn{4}{c}{ Pakan perlakuan (Feed treatments) } \\
\cline { 2 - 5 } & A & B & C & D \\
\hline Protein (Crude protein) & 30.12 & 31.09 & 33.48 & 34.15 \\
Lemak (Fat) & 7.88 & 8.24 & 8.23 & 7.97 \\
Kadar abu (Ash content) & 9.47 & 10.09 & 10.07 & 10.11 \\
Serat kasar (Crude fiber) & 2.10 & 3.32 & 1.72 & 1.14 \\
BETN (NFE) & 50.43 & 47.23 & 46.5 & 46.62 \\
\hline E asam lemak tak jenuh n-6 (n-6 fatty acids) & 1.94 & 2.60 & 2.69 & 2.89 \\
(\%dari total lemak (\% of total fat)) & $(0.15 \%)$ & $(0.21 \%$ & $(0.22 \%)$ & $(0.23 \%$ \\
- Gamma linolenic acid C18:3n-6 & 0.04 & 0.08 & 0.13 & 0.23 \\
- Linoleic acid C18:2n-6c & 1.31 & 1.90 & 1.93 & 1.94 \\
- Arachidonic acid C20:4n-6 & 0.25 & 0.29 & 0.28 & 0.29 \\
- Eicosedienoic acid C20:2n-6 & 0.25 & 0.25 & 0.26 & 0.34 \\
- Eicosetrienoic acid C20:3n-6 & 0.29 & 0.08 & 0.09 & 0.09 \\
\hline E asam lemak tak jenuh n-3 (n-3 fatty acids) & 19.64 & 23.84 & 25.26 & 25.88 \\
(\%dari total lemak (\% of total fat)) & $(1.55 \%$ & $(1.96 \% /$ & $(2.08 \%)$ & $(2.06 \%$ \\
- Alpha linolenic acid C18:3n-3 & 16.86 & 19.91 & 20.3 & 20.96 \\
- Eicosatrienoic acid C20:3n-3 & 0.04 & 0.05 & 0.04 & 0.02 \\
- Eicosapentaenoic acid C20:5n-3 & 1.55 & 1.61 & 1.69 & 1.90 \\
- Docosahexaenoic acid C22:6n-3 & 1.17 & 2.13 & 2.45 & 2.85 \\
- Docosadienoic acid C22:2n-3 & 0.02 & 0.14 & 0.15 & 0.15 \\
\hline
\end{tabular}

Keterangan (Note):

$\mathrm{A}=$ Pelet komersial dengan $0 \% \mathrm{~S}$. platensis, $\mathrm{B}=$ Pelet komersial dengan penambahan $1 \% \mathrm{~S}$. platensis, $\mathrm{C}=$ Pelet komersial dengan penambahan $2 \%$ S. platensis, dan $D=$ Pelet komersial dengan penambahan $3 \%$ S. platensis $(A=$ Commercial pellet with $0 \%$ Spirulina, B = Commercial pellet with addition of $1 \%$ Spirulina, $C=$ Commercial pellet with addition of $2 \%$ Spirulina, $D=$ Commercial pellet with addition of $3 \%$ Spirulina). BETN = Bahan ekstrak tanpa nitrogen; NFE = Nitrogen free extract

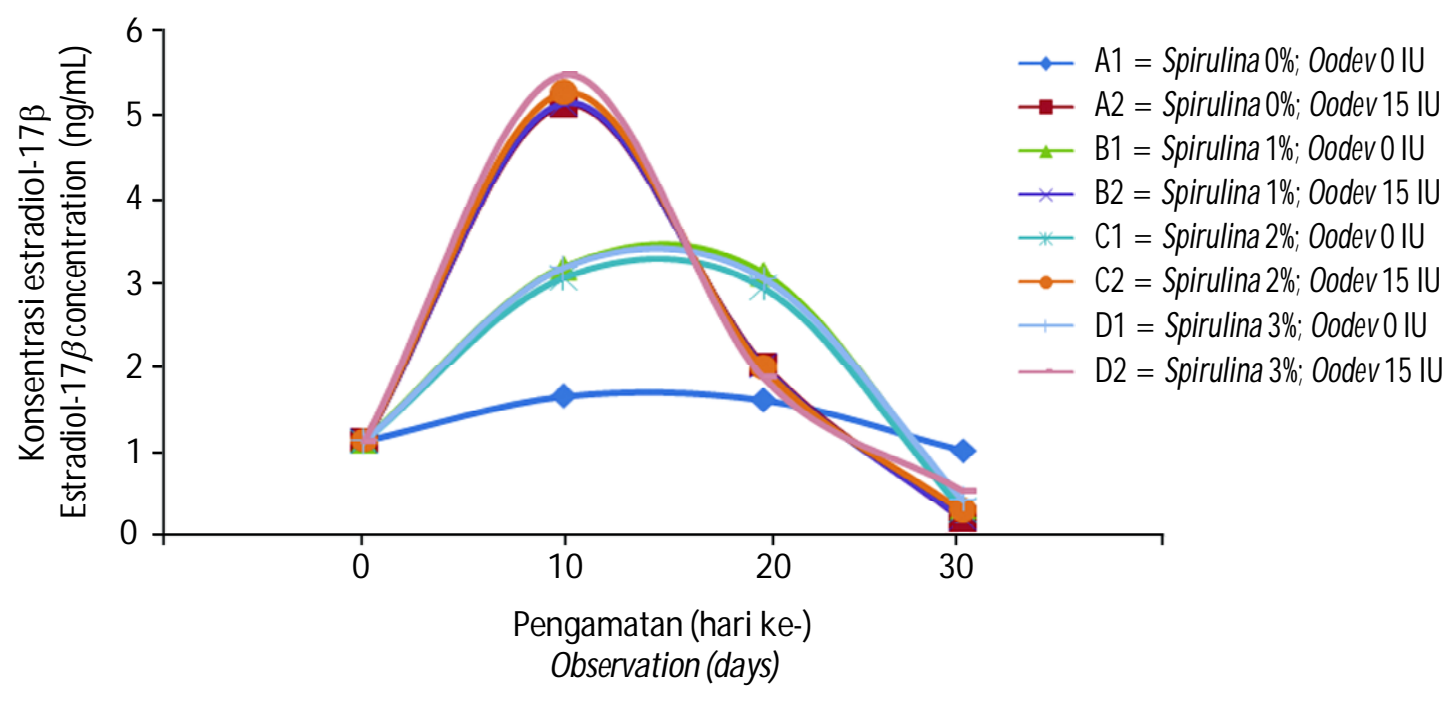

Gambar 1. Kadar estradiol-17 $\beta$ dalam plasma darah ikan lele (Clarias sp.) yang diberi perlakuan berbeda pada pengambilan sampel hari ke-0, 10, 20, dan ke-30

Figure 1. Levels of estradiol-17 $\beta$ in blood plasma of catfish (Clarias sp.) treated differently on day $0,10,20$, and 30 


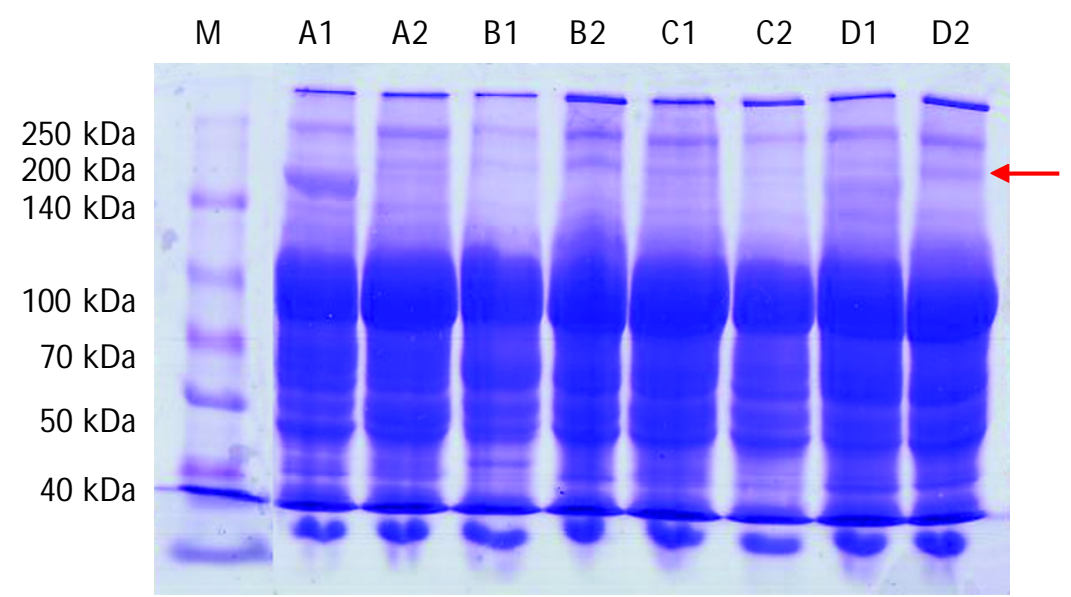

Gambar 2. Visualisasi vitelogenin dalam plasma darah induk ikan lele, ditunjukkan dengan tanda panah $(\mathrm{M}=$ marker; $\mathrm{A} 1=$ perlakuan $\mathrm{A} 1 ; \mathrm{A} 2=$ perlakuan $\mathrm{A} 2 ; \mathrm{B} 1=$ perlakuan $\mathrm{B} 1 ; \mathrm{B} 2=$ perlakuan $\mathrm{B} 2 ; \mathrm{Cl}=$ perlakuan $\mathrm{C} 1 ; \mathrm{C2}=$ perlakuan $\mathrm{C2} ; \mathrm{D} 1$ = perlakuan $\mathrm{D} 1 ; \mathrm{D} 2$ = perlakuan $\mathrm{D} 2$ )

Figure 2. Visualization of vitellogenin in blood plasma of catfish broodstock, shown by arrow $(M=$ marker; $\mathrm{A1}=$ treatment $\mathrm{A1} ; \mathrm{A2}=$ treatment $\mathrm{A2} ; \mathrm{B1}=$ treatment $\mathrm{B} 1 ; \mathrm{B2}=$ treatment $\mathrm{B2} ; \mathrm{C1}=$ treatment $\mathrm{C} 1 ; \mathrm{C2}=$ treatment $\mathrm{C2} ; \mathrm{D} 1=$ treatment $\mathrm{D} 1 ; \mathrm{D2}=$ treatment $\mathrm{D} 2$ )

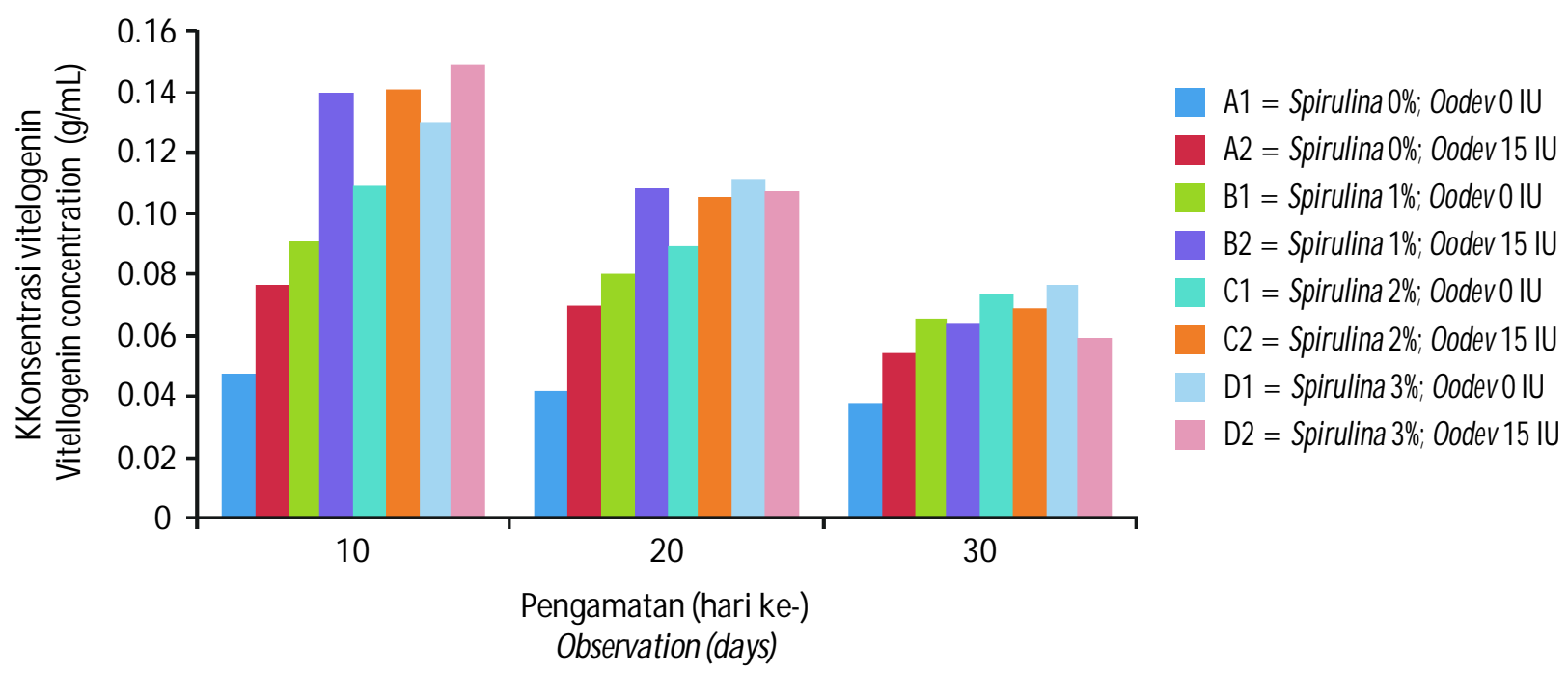

Gambar 3. Konsentrasi vitelogenin plasma darah induk ikan lele

Figure 3. Vitellogenin concentration in blood plasma of catfish broodstock

kuan D2 pada hari ke-10; $0,04 \mathrm{~g} / \mathrm{mL}$ pada perlakuan A1 sampai $0,11 \mathrm{~g} / \mathrm{mL}$ perlakuan D2 pada hari ke-20 dan $0,04 \mathrm{~g} / \mathrm{mL}$ perlakuan A1 sampai $0,06 \mathrm{~g} / \mathrm{mL}$ perlakuan D2 pada hari ke-30.

Hasil ini membuktikan bahwa perlakuan penyuntikan Oodev menginduksi percepatan proses vitelogenin dibandingkan tanpa hormon. Selain itu, Oodev dapat mempercepat proses maturasi. Hari ke-30, konsentrasi vitelogenin dalam darah semakin berkurang karena sudah mereduksi kematangan akhir dan terakumulasi ke dalam gonad.

Selama 30 hari pengamatan menunjukkan terjadinya perubahan konsentrasi vitelogenin pada setiap perlakuan. Hari ke-10 adalah konsentrasi vitelogenin tertinggi dibandingkan dengan hari ke-20 dan hari ke-30. Pada hari ke-10 tersebut, konsentrasi vitelogenin pada perlakuan kombinasi Oodev dengan S. platensis lebih tinggi dibandingkan perlakuan lainnya. Hal ini menunjukkan konsistensi estradiol di mana puncaknya juga terjadi pada hari ke-10.

\section{Gonado Somatic Index}

Hasil pengamatan terhadap nilai GSI tersaji pada Gambar 4. Nilai GSI induk ikan uji berbeda antar perlakuan khususnya terhadap kontrol sebesar 5,38\% kecuali perlakuan $\mathrm{C} 1$ sebesar 7,19\%dengan C2 sebesar 7,15\%dan D1 sebesar 7,32\%dengan perlakuan D2 sebesar 7,30\% pada hari ke-10. Persentase nilai mengalami peningkatan untuk semua perlakuan meski- 


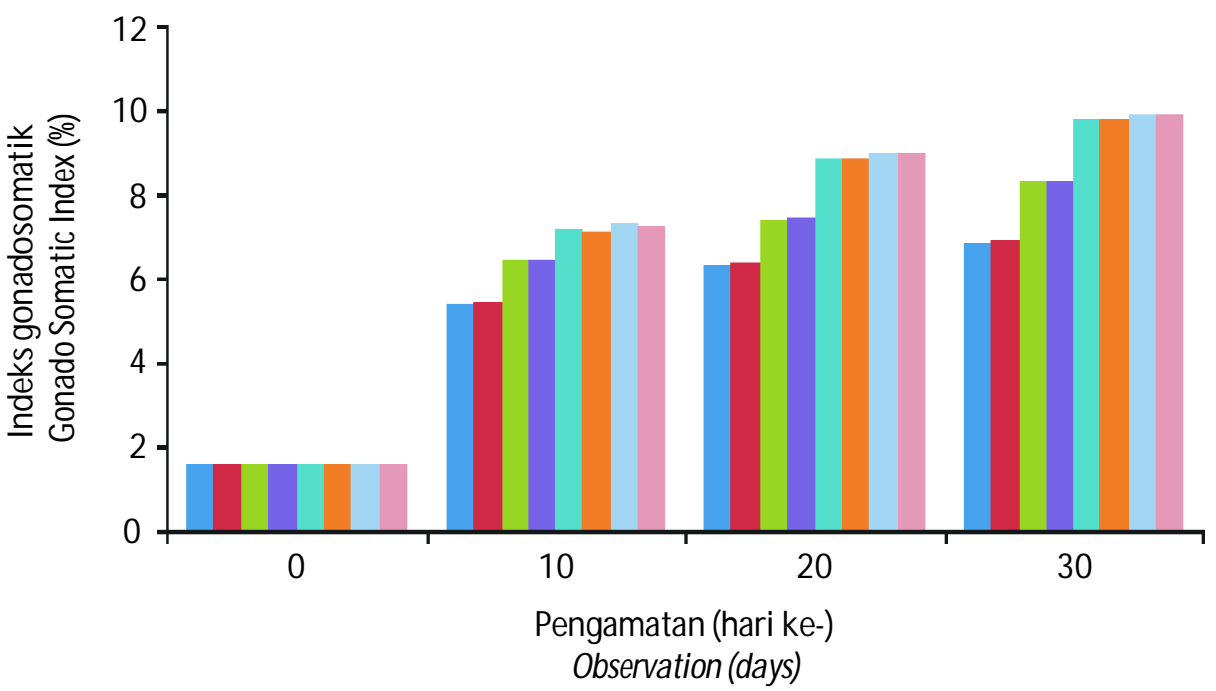

$\mathrm{Al}=$ Spirulina 0\% Oodev $0 \mathrm{IU}$

$A 2=$ Spirulina 0\% Oodev $15 \mathrm{IU}$

$B 1=$ Spirulina $1 \%$ Oodev $0 I U$

$B 2=$ Spirulina $1 \%$ Oodev $15 \mathrm{IU}$

$\mathrm{Cl}=$ Spirulina $2 \%$ Oodev $0 \mathrm{IU}$

$\mathrm{C2}=$ Spirulina $2 \%$ Oodev $15 \mathrm{IU}$

D1 $=$ Spirulina $3 \%$ Oodev $0 \mathrm{IU}$

D2 = Spirulina 3\% Oodev $15 \mathrm{IU}$

Gambar 4. Nilai indeks gonadosomatik induk ikan lele selama 30 hari yang diberi kombinasi suplemen Spirulina dan Oodev

Figure 4. The Gonado Somatic Index (GSI) value of catfish broodstock during 30 days given combination of supplement Spirulina and Oodev

pun nilai tersebut berbeda-beda, di mana nilai GSI awal (hari ke-0) sebesar 1,63\% Nilai GSI tertinggi ditemukan pada perlakuan D1 sebesar 7,32\% dan D2 sebesar 7,30\% Nilai ini lebih tinggi dibanding perlakuan A1-C2. Sepuluh hari kemudian (hari ke-20), nilai GSI induk ikan uji mengalami peningkatan lagi. Nilai GSI tertinggi diperoleh pada perlakuan D1 sebesar $9,02 \%$ dan D2 sebesar 9,01\% di mana peningkatannya sebesar $1,71 \%$ Nilai ini lebih tinggi dibanding perlakuan A1-C2. Pada akhir perco baan (hari ke30), nilai GSI induk ikan uji tertinggi juga diperoleh pada perlakuan D1 sebesar $9,93 \%$ dan D2 sebesar $9,94 \%$ dengan peningkatan sebesar $0,93 \%$

\section{Fekunditas}

Nilai fekunditas pada perlakuan A1 sampai dengan perlakuan D2 adalah $40.996 \pm 182$ butir sampai dengan $81.953 \pm 1.639$ butir (Tabel 2). Perlakuan B1, $\mathrm{B} 2, \mathrm{C} 1, \mathrm{C2}$, D1, dan D2 berbeda nyata dengan kontrol (A1) dan A2. Hasil analisis statistik menunjukkan bahwa fekunditas dipengaruhi nyata $(P<0,05)$ oleh faktor suplementasi Spirulina 1\% 2\% dan 3\% Faktor penyuntikan Oodev tidak memberikan pengaruh nyata $(P>0,05)$ terhadap fekunditas ikan lele, serta tidak terdapat interaksi antara kedua faktor tersebut dan fekunditas tertinggi ditunjukkan oleh perlakuan D1 dan D2.

\section{Derajat Tetas Telur}

Hasil pengamatan derajat tetas telur pada perlakuan A1 sampai dengan D2 berkisar 74,81\% 2,12 sampai dengan 90,70\% 2,06 (Tabel 2). Hasil analisis statistik menunjukkan bahwa perlakuan D2 berbeda nyata dengan perlakuan $\mathrm{D} 1, \mathrm{C} 2, \mathrm{C} 1, \mathrm{~B} 2, \mathrm{~B} 1, \mathrm{~A} 2$, dan
A1. Perlakuan $\mathrm{C} 2$ dan $\mathrm{C} 1$ berbeda nyata terhadap $\mathrm{B} 2$, $\mathrm{B} 1, \mathrm{~A} 2$, dan $\mathrm{A} 1$ tapi tidak berbeda nyata antara perlakuan $\mathrm{C} 2$ dan $\mathrm{C} 1$. Perlakuan B1 dan B2 berbeda nyata dengan $\mathrm{A} 2$ dan $\mathrm{A} 1$ tetapi tidak berbeda nyata antara perlakuan B1 dan B2 dan perlakuan A2 dan A1 tidak berbeda nyata. Faktor yang berpengaruh nyata $(P<0,05)$ terhadap derajat penetasan adalah suplementasi Spirulina. Faktor penyuntikan Oodev tidak memberikan pengaruh nyata $(P>0,05)$ terhadap derajat tetas telur ikan lele, serta tidak terdapat interaksi antara kedua faktor tersebut dan derajat tetas telur tertinggi ditunjukkan oleh perlakuan D1 dan D2.

\section{Sintasan Larva}

Hasil pengamatan sintasan larva pada perlakuan A1 sampai dengan D2 berkisar 75,01\% 2,67 sampai dengan 92,94\% 0,06 (Tabel 2). Perlakuan B1 dan B2 berbeda nyata dengan $\mathrm{A} 2$ dan $\mathrm{A} 1$ tetapi tidak berbeda nyata antara perlakuan B1 dan B2 dan perlakuan A2 dan A1 tidak berbeda nyata. Hasil analisis statistik sintasan larva menunjukkan bahwa perlakuan D1 dan $\mathrm{D} 2$ berbeda nyata terhadap perlakuan $\mathrm{C} 2, \mathrm{C} 1, \mathrm{~B} 2$, $\mathrm{B} 1, \mathrm{~A} 2$, dan $\mathrm{A} 1$ tetapi tidak berbeda nyata antara perlakuan D1 dan D2. Perlakuan $\mathrm{C} 2$ dan $\mathrm{C} 1$ berbeda nyata terhadap B2, B1, A2, dan A1 tapi tidak berbeda nyata antara perlakuan C2 dan C1. Sintasan larva tertinggi ditunjukkan oleh perlakuan D1 dan D2.

\section{Kadar Asam Lemak Telur dan Larva}

Hasil analisis kadar asam lemak telur dan larva disajikan pada Gambar 5. Hasil tersebut menunjukkan bahwa kadar asam lemak dari telur dan larva dipengaruhi oleh penambahan Spirulina pada pakan, sedangkan Oodev berpengaruh terhadap nilai konsen- 
Tabel 2. Fekunditas, derajat tetas telur, dan sintasan larva ikan lele yang diberi pakan diperkaya kombinasi Spirulina (Sp.) dan disuntik dengan Oodev (Od.)

Table 2. Fecundity, hatching rate, and survival rate of catfish fed diet supplemented with Spirulina (Sp.) and injected with Oodev (od.)

\begin{tabular}{|c|c|c|c|}
\hline $\begin{array}{l}\text { Perlakuan } \\
\text { Treatments }\end{array}$ & $\begin{array}{l}\text { Fekunditas (butir/g induk) } \\
\text { Fecundity (eggs/g broodstock) }\end{array}$ & $\begin{array}{c}\text { Derajat penetasan } \\
\text { Hatching rate }(\%)\end{array}$ & $\begin{array}{c}\text { Sintasan } \\
\text { Survival rate (\%) }\end{array}$ \\
\hline Al (Sp. 0\% Od. 0 IU) & $40,996 \pm 1,819^{a}$ & $74.81 \pm 2.1213^{\mathrm{a}}$ & $75.01 \pm 2.6729^{a}$ \\
\hline A2 (Sp. 0\% Od. 15 IU) & $40,460 \pm 556^{a}$ & $75.15 \pm 2.2610^{\mathrm{a}}$ & $75.46 \pm 1.7819^{a}$ \\
\hline B1 (Sp. 1\% Od. 0 IU) & $53,979 \pm 864^{b}$ & $83.53 \pm 1.1511^{b}$ & $86.45 \pm 1.4991^{b}$ \\
\hline B2 (Sp. 1\% Od. 15 IU) & $54,036 \pm 1,125^{b}$ & $83.65 \pm 2.0219^{b}$ & $87.18 \pm 1.8173^{b}$ \\
\hline $\mathrm{Cl}(\mathrm{Sp} .2 \%$ Od. $0 \mathrm{IU})$ & $75,280 \pm 1,492^{c}$ & $88.05 \pm 1.0216^{c}$ & $89.43 \pm 0.8132^{c}$ \\
\hline C2 (Sp. 2\% Od. 15 IU) & $77,280 \pm 76^{c}$ & $88.47 \pm 1.9207^{c}$ & $89.95 \pm 0.8061^{c}$ \\
\hline D1 (Sp. 3\% Od. 0 IU) & $80,783 \pm 2,094^{d}$ & $90.67 \pm 1.79431^{d}$ & $92.65 \pm 0.5020^{d}$ \\
\hline D2 (Sp. 3\% Od. 15 IU) & $81,953 \pm 1,639^{d}$ & $90.70 \pm 2.06320^{d}$ & $92.94 \pm 0.0636^{d}$ \\
\hline
\end{tabular}

Keterangan (Note):

Angka yang diikuti oleh huruf superscript yang berbeda pada kolom yang sama menunjukkan perbedaan nyata $(\mathrm{P}<$ $0,05)$ (Different superscript letters in the same column indicate significantly difference $(P<0.05))$

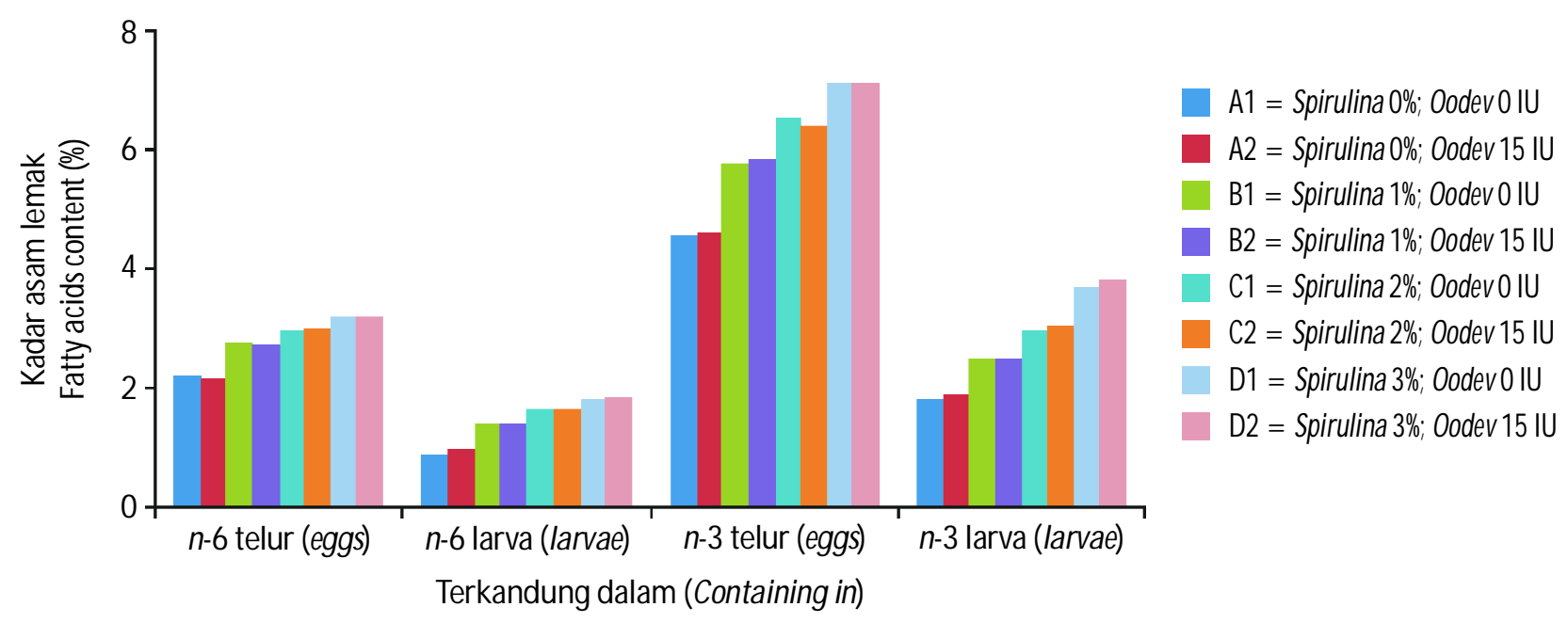

Gambar 5. Kadar asam lemak n-6 dan n-3 yang terkandung dalam telur dan larva ikan lele selama 30 hari pemeliharaan dengan menggunakan Gas Kromatografi

Figure 5. Content of n-6 and n-3 fatty acids in the catfish eggs and larvae based on Gas Chromatography analysis for 30 days rearing

trasi estradiol, vitelogenin, dan GSI. Hal ini dapat dilihat dari hasil analisis bahwa pakan perlakuan dengan kadar asam lemak n-6 yang lebih rendah yakni sebesar 0,15\%pada pakan uji A (kontrol) mengandung asam lemak n-6 pada telur 2,18\%(A1) dan 2,17\%(A2), pada larva sebesar 0,90\%(A1) dan 0,95\%(A2). Kadar asam lemak $n-6$ tertinggi pada pakan uji $D$ sebesar 0,23\% mengandung asam lemak n-6 pada telur 3,19\%(D1) dan 3,22\%(D2), pada larva sebesar 1,79\%(D1) dan 1,85\% (D2). Pakan perlakuan dengan kadar asam lemak n-3 yang lebih rendah yakni sebesar 1,55\%pada pakan uji A mengandung asam lemak $n-3$ pada telur 4,58\%(A1) dan 4,61\%(A2), pada larva sebesar 1,79\%(A1) dan 1,88\% (A2). Kadar asam lemak n-3 pada pakan uji D sebesar 2,06\%mengandung asam lemak n-3 pada telur 7,11\% (D1) dan 7,12 \%(D2), pada larva sebesar 3,70\%(D1) dan $3,81 \%(D 2)$.

\section{Bahasan}

Suplementasi Spirulina berpengaruh karena mekanisme vitelogenesis sampai pengaturan ukuran telur ikan dalam gonad bergantung pada kecukupan nutrien yang tersedia. Asam lemak n-6 dan n-3 khususnya GLA yang dikandung oleh Spirulina (Tabel 1) dapat diduga memengaruhi sifat fluiditas dari membran sel. Perubahan fluiditas membran yang diakibatkan oleh perubahan komposisi asam lemak akan memengaruhi metabolisme sel melalui perubahan akti- 
vitas enzim-enzim yang ada pada membran sel sehingga vitelogenin masuk dengan mudah dan diserap o osit (Sargent et al., 2002). Selanjutnya asam lemak tak jenuh pada pakan induk memengaruhi fekunditas, derajat penetasan, dan sintasan larva (Mokoginta, 1992; Mokoginta et al., 1995; Izquierdo et al., 2001).

Faktor lain selain pakan bernutrisi yang memengaruhi reproduksi adalah proses hormonal atau endokrin. Hormon akan bekerja apabila mendapat signal dari lingkungan, namun hal tersebut telah dapat dimanipulasi dengan menambahkan hormon dari luar. Hasil penelitian secara keseluruhan menunjukkan bahwa penambahan Spirulina pada pakan dan penyuntikan Oodev mampu mempercepat waktu pematangan gonad dan meningkatkan performa reproduksi induk lele.

Penyuntikan hormon FSH+ AD yang dikandung Oodev mampu mempercepat pertumbuhan oosit dengan merangsang pembentukan folikel dan mempercepat proses vitelogenesis karena sangat banyak mengandung unsur daya kerja FSH dan sedikit LH. FSH atau GTH I akan merangsang terjadinya lonjakan kadar GnRH yang selanjutnya memengaruhi pituitari untuk memproduksi gonadotropin (Bolamba et al., 1992; Zairin et al., 2001). Penyuntikan Oodev (mengandung bahan aktif FSH+AD) yang dikombinasikan dengan Spirulina mampu mempercepat pertumbuhan oosit dan pematangan gonad pada minggu ke10 (Gambar 1). Hasil ini membuktikan adanya kerja dari hormon eksogen pada sel-sel folikel oosit induk ikan lele. Nagahama (1995) menyatakan bahwa perkembangan oosit dari previtelogenesis ke vitelogenesis terjadi karena peningkatan produksi estradiol17 $\beta$. Hal ini juga ditunjukkan dari hasil penelitian ini, di mana adanya peningkatan estradiol-17 $\beta$ pada minggu ke-10 setelah penyuntikan. Estradiol-17 $\beta$ selanjutnya masuk ke dalam sistem vaskuler dan merangsang hati untuk menyintesis ke dalam oosit dan menyekresikan vitelogenin ke dalam peredaran darah, kemudian vitelogenin akan terdisposisikan ke dalam oosit dengan cara endositosis spesifik protein. Sementara itu, kandungan asam lemak esensial yang dikandung Spirulina mampu meningkatkan kualitas vitelogenin yang diserap oleh oosit yang nantinya dimanfaatkan untuk perkembangan embrio hingga menetas menjadi larva. Mokoginta (1992) menyatakan bahwa komposisi asam lemak esensial pada telur (oosit) dapat memengaruhi terhadap stadia awal proses embriogenesis.

Konsentrasi estradiol-17 $\beta$ pada penelitian ini menunjukkan peningkatan terjadi pada hari ke-10 untuk semua perlakuan. Fluktuasi konsentrasi estradiol$17 \beta$ setelah penyuntikan Oodev yakni pada perlakuan A2, B2, C2, dan D2 menunjukkan nilai yang lebih tinggi dibandingkan dengan tanpa penyuntikan (perlakuan A1, B1, C1, dan D1). Hal ini mengindikasikan proses perkembangan kematangan gonad lebih awal. Selanjutnya menurun mulai hari ke-20 hingga hari ke30. Penurunan ini menggambarkan kematangan gonad akhir. Kematangan gonad ini lebih cepat setelah penyuntikan Oodev dibanding tanpa Oodev. Hasil penelitian Rachman (2013) menunjukkan hasil yang sama bahwa profil estradiol-17 $\beta$ dalam darah menunjukkan penurunan mulai dari hari ke-21 setelah diinduksi PMSG. Hal ini mengindikasikan bahwa pada gonad terjadi umpan balik positif ke otak untuk menyintesis LH sebagai lanjutan perkembangan gonad.

Vitelogenin sebagai bahan baku kuning telur mempunyai bobot molekul tinggi, di mana bobot molekul vitelogenin induk ikan secara umum yang sedang bunting diketahui antara 140-220 kDA (Tyler, 1991; Komatsu \& Hayashi, 1997). Bobot molekul vitelogenin induk ikan lele (Clarias sp.) hasil penelitian ini terdeteksi 200 kDa (Gambar 2). Hasil ini sesuai dengan penelitian (Manohar et al., 2005) bahwa bobot molekul induk ikan lele (Clarias gariepinus) 200 kDa. Bila dibandingkan dengan bobot molekul ikan lainnya vitelogenin ikan lele lebih berat. Vitelogenin ini berupa glikofosfoprotein yang mengandung $20 \%$ lemak, terutama fosfolipid, trigliserida, lipoprotein, dan kolesterol. Molekul-molekul ini akan menjadi sumber energi untuk proses pembentukan oosit yang berperan dalam perkembangan embrio dan viabilitas larva (Tang \& Affandi, 2000; Salerno et al., 2002). Vitelogenesis, dicirikan oleh bertambah banyaknya volume sitoplasma yang berasal dari luar sel, yakni kuning telur atau vitelogenin, oleh karena itu, maka kualitas telur sangat ditentukan selama proses tersebut berlangsung. Beberapa faktor seperti kualitas pakan, lingkungan, dan aktivitas hormon sangat berperan untuk menunjang keberhasilan proses tersebut (Fujaya, 2004).

Berdasarkan nilai pengukuran konsentrasi vitelogenin dalam darah terlihat adanya percepatan peningkatan dan penurunan periode vitelogenesis yang berbeda antar perlakuan. Dengan adanya induksi Oodev dan suplementasi Spirulina periode vitelogenesis mengalami periode peningkatan dan penurunan yang berbeda bila dibandingkan dengan kontrol (Gambar 2). Hasil pengamatan terhadap konsentrasi vitelogenin menunjukkan bahwa perlakuan penyuntikan hormon (Oodev) dan suplementasi Spirulina menginduksi percepatan proses vitelogenin dibandingkan tanpa perlakuan kombinasi yang selanjutnya dapat mempercepat proses maturasi pada hari ke-20 hingga hari ke-30. Pada hari ke-30 konsentrasi vitelogenin dalam darah semakin berkurang. Pengurangan (penurunan) ini disebabkan oleh karena sudah mereduksi kematangan akhir dan sudah terdistribusi (teraku- 
mulasi) ke dalam telur (oosit) di dalam gonad. Pada hari ke-10 tersebut, konsentrasi vitelogenin pada perlakuan kombinasi Oodev dengan Spirulina lebih tinggi dibandingkan perlakuan lainnya. Hal ini menunjukkan konsistensi estradiol-17 $\beta$ di mana puncaknya juga terjadi pada hari ke-10. Rafiuddin (2013) menyebutkan bahwa ikan patin yang disuntik dengan Oodev meningkat ekspresi gen aromatase dan FSH yang menunjukkan terjadi perkembangan awal di go nad pada hari ke-10.

Seiring dengan perkembangan gonad, di akhir pemeliharaan diiringi kurangnya konsentrasi vitelogenin. Peningkatan nilai GSI mengalami peningkatan oleh karena penyerapan vitelogenin di oosit. GSI semakin meningkat seiring dengan lama pemeliharaan. Peningkatan nilai GSI setiap 10 hari disebabkan oleh perkembangan oosit. Peningkatan kecepatan gonad sebagai akibat dari peningkatan kadar Spirulina yang dilihat dari nilai GSI menunjukkan bahwa penimbunan vitelogenin terjadi semakin cepat.

GSI merupakan rasio gonad dengan bobot badan induk. Nilai GSI dengan kematangan gonad memiliki hubungan linier sehingga berdampak pada fekunditas yang dihasilkan. Semua perlakuan menunjukkan nilai GSI yang terus meningkat seiring dengan waktu pemeliharaan (Gambar 3). Pemberian suplementasi Spirulina 3\%yang dikombinasikan dengan penyuntikan Oodev 15 IU memberikan hasil yang terbaik untuk parameter GSI. Hasil penelitian ini sejalan dengan penelitian Mayasari (2012) dan Utiah (2006) bahwa nilai GSI akan lebih besar bila ditambahkan nutrisi pada pakan induk dibandingkan tanpa suplementasi.

Nilai GSI cenderung meningkat karena vitellin disalurkan ke gonad hingga mencapai ukuran maksimal. Proses vitelogenesis ini menyebabkan nilai Gonado Somatic Index (GSI) ikan meningkat (Cerda et al., 1996). Hal ini menunjukkan bahwa proses vitelogenesis atau sintesis vitelogenin dilakukan di hati dan selanjutnya disalurkan ke dalam gonad ikan melalui pembuluh darah (McMillan, 2007; Nagahama et al., 2008). Selama pertumbuhan oosit terjadi peningkatan GSI sampai $20 \%$ atau lebih, ini disebabkan estradiol$17 \beta$ beredar menuju hati memasuki jaringan dengan cara difusi dan secara spesifik merangsang sintesis vitelogenin (Tyler, 1991).

Peningkatan nilai GSI selanjutnya akan memengaruhi fekunditas. Fekunditas merupakan jumlah telur yang dihasilkan (butir/g induk). Berdasarkan uji statistik, faktor yang memberikan pengaruh nyata $(P<0,05)$ terhadap fekunditas hanyalah faktor Spirulina, sementara Oodev tidak memberi pengaruh yang nyata $(P>0,05)$, serta tidak ada interaksi antara kedua faktor tersebut. Jika dibandingkan antar perlakuan, fekunditas tertinggi dihasilkan oleh perlakuan
D1 dan D2 yakni pada dosis Spirulina 3\%dan kombinasi antara Spirulina dengan Oodev 15 IU (Tabel 2). Hasil penelitian ini didukung oleh pernyataan Kamler (1992) bahwa hewan yang diberi pakan berkualitas baik maka fekunditasnya akan semakin tinggi, sebaliknya pakan yang buruk dapat menurunkan jumlah telur. Dengan kata lain, faktor yang paling memengaruhi besar kecilnya fekunditas adalah kualitas pakan yang selanjutnya akan memengaruhi derajat tetas telur.

Faktor Spirulina memberi pengaruh yang nyata $(P<0,05)$ terhadap derajat penetasan, sementara faktor Oodev tidak memberi pengaruh yang berbeda nyata $(P>0,05)$, serta tidak terdapat interaksi antar kedua faktor. Derajat penetasan terbaik ditunjukkan oleh perlakuan D2. Perlakuan B1, B2, C1, C2 juga menunjukkan angka yang lebih tinggi dan berbeda nyata jika dibandingkan dengan kontrol. Perlakuan A2 yang hanya disuntikkan Oodev $15 \mathrm{lU} / \mathrm{kg}$ saja menghasilkan derajat tetas yang tidak berbeda nyata dengan kontrol. Hal ini menunjukkan bahwa hormon bukan merupakan faktor yang memengaruhi derajat tetas telur pada penelitian ini. Spirulina memengaruhi karena nutrien penting seperti asam lemak esensial yang tersedia pada pakan berguna untuk meningkatkan perkembangan morfologi telur seperti pembentukan atau penyusunan struktur membran sel dan sebagai prekursor prostaglandin sehingga telur tidak rentan terhadap kerusakan dan derajat penetasan menjadi lebih baik. Izquierdo et al. (2001) melaporkan bahwa peningkatan persentase telur normal dan sehat seiring dengan peningkatan kandungan EFA dalam pakan induknya, serta terkait dengan komposisi asam lemak yang terdapat dalam telur itu sendiri.

Telur yang menetas selanjutnya dipelihara hingga larva berumur empat hari. Berdasarkan uji statistik, faktor Spirulina memberi pengaruh yang berbeda nyata $(P<0,05)$ terhadap sintasan larva. Nilai sintasan terbaik ditunjukkan oleh perlakuan D1 dan D2. Faktor nutrisi yang memengaruhi sintasan larva ini juga ditunjukkan oleh penelitian-penelitian sebelumnya di mana, peningkatan komposisi asam lemak esensial pada pakan meningkatkan derajat tetas dan sintasan larva pada ikan rabbitfish. Selain itu, peningkatan asam lemak esensial pada pakan juga mampu meningkatkan bobot larva ikan dan meningkatkan ketahanan terhadap perubahan tekanan osmotik sehingga sintasannya semakin tinggi (Izquierdo et al., 2001).

Kandungan asam lemak pada telur yang lebih tinggi akan menurun setelah telur menetas menjadi larva. Fakta ini membuktikan bahwa Spirulina yang diberikan melalui pakan induk akan diakumulasikan oleh induk pada saat pembentukan telur dan dimanfaatkan saat perkembangan larva. Nutrisi Spirulina memang sangat dibutuhkan dalam perkembangan 
embrio dan larva. Asam lemak esensial yang terkandung dalam telur berpengaruh pada stadia awal embriogenesis dan akan menentukan apakah embrio tersebut akan berkembang atau tidak (Mokoginta, 1992). Hal ini berhubungan dengan dimulainya proses pembentukan jaringan dan organ-organ tubuh pada saat telur menetas, seperti terbentuknya kepala, abdomen, dan ekor. Makin lama larva hidup dengan mengandalkan energi cadangan, makin baik kualitas larva tersebut. Hal ini sesuai dengan yang dikemukakan oleh Mokoginta et al. (1995) bahwa asam lemak yang diberikan dalam pakan induk mempunyai suatu peranan penting dalam proses reproduksi, pada tahap awal larva belum mendapat pakan dari luar, larva masih mengandalkan kandungan kuning telur sebagai sumber cadangan energi utama yang memengaruhi sintasan larva.

\section{KESIMPULAN DAN SARAN}

Pakan perlakuan yang dikombinasikan dengan penyuntikan Oodev yang terbaik untuk memperbaiki performa induk, kualitas telur dan larva adalah pada perlakuan D2 (Spirulina 3\% Oodev 15 IU). Suplementasi Spirulina pada pakan yang dikombinasikan dengan Oodev dapat mempercepat kematangan gonad induk dan menstimulasi kinerja reproduksi terutama pada perkembangan gonad, kualitas telur, larva, dan sintasan larva.

Suplementasi Spirulina pada pakan yang dikombinasikan dengan hormon Oodev (Spirulina 3\% Oodev 15 IU) dapat dijadikan acuan untuk mempercepat kematangan gonad dan menstimulasi kinerja reproduksi induk ikan jenis lainnya seperti Pangasius sp.

\section{DAFTAR ACUAN}

Bolamba, D., Matton, P., Estrada, R., \& Dufour, J.J. (1992). Effect pregnant mare serum gonadotropin on follicular population and ovulation rates in prepubertal gilts with two morphologically different ovarium types. J. Anim. Sci., 70, 1916-1992.

Cerda, J.B.G., Calman, G.J., Lafleur, J.r., \& Limesand, S. (1996). Pattern of vitellogenesis and follicle maturational competence during the ovarian folicular cycle of Fundulus heteroclitus. Gen. Comp. Endocrinol., 103, 24-35.

Diraman, H., Koru, E., \& Dibeklioglu. (2009). Fatty acid profile of Spirulina platensis used as a food supplement. The Israeli Journal of Aquaculture-Bamidgeh, 61(2), 134-142.

Fujaya, Y. (2004). Fisiologi ikan. PT Rineka Cipta. Jakarta, $159 \mathrm{hlm}$.

Fukada, S., Sakai, N., Adachi, S., \& Nagahama, Y. (1994). Steroidogenesis in the ovarian follicle of medaka (Oryzias latipes, a daily spanner) during oocyte maturation. Develop. Growth Differ., 36, 8188.

Izquierdo, M.S., Ferna'ndez-Palacios, H., \& Tacon, A.G.J. (2001). Effect of broodstock nutrition on reproductive performance of fish. Aquaculture, 197, 25-42.

Jongkon, P., \& Chanagun, C. (2011). The effect of Spirulina platensis and Cladophora algae on the growth performance, meat quality and immunity stimulating capacity of the African sharptooth catfish (Clarias gariepinus). International of Journal Agriculture and Biology, p. 1560-8530.

Kamler, E. (1992). Early life history of fish, an energetic approach. Chapman and Hall. London, 181 pp.

Komatsu, M., \& Hayashi, S. (1997). Pharmacological dose of estradiol-17 $\beta$ induces vitellogenin synthesis in cultured hepatocytes of immature eel Anguilla japonica. Fish Science, 63, 989-994.

Lu, J., \& Takeuchi, T. (2004). Spawning and egg quality of the tilapia Oreochromis niloticus fed solely on raw Spirulina troughout three generations. Aquaculture, 234, 625-640.

Manohar, D., Damodar, R.G., Sreenivasulu, G., Senthilkumaran, B., \& Aparna, D.G. (2005). Purification of vitellogenin from the air breathing catfish, Clarias gariepinus. Fish Physiol. Biochem., 31, 235-239.

Mayasari, N. (2012). Pemacuan kematangan gonad ikan lele dumbo Clarias sp. betina dengan kombinasi hormon PMSG dan Spirulina. Tesis. Institut Pertanian Bogor. Bogor, $80 \mathrm{hlm}$.

Meng-Umphan, K. (2009). Growth performance, sex hormone levels and maturation ability of pla poa (Pangasius bocourti) fed with Spirulina suplementary pellet and hormone application. International of Journal Agriculture Biology, 11, 458-462.

McMillan, D.B. (2007). Fish histology. Female reproductive systems Departemen of Biology. The University of Western Ontario London. Ontario Canada, 503 pp.

Mokoginta, I. (1992). Essential fatty acid requirement of catfish (Clarias batracus Linn.) for broodstock development. Disertasi. Sekolah Pascasarjana Institut Pertanian Bogor. Bogor, $80 \mathrm{hlm}$.

Mokoginta, I., Moeljohardjo, D.S., Takeuchi, T., Sumawidjaja, K., \& Fardiaz, D. (1995). Kebutuhan asam lemak esensial untuk perkembangan induk ikan lele; Clarias batracus Linn. Jurnal IImu-IImu Perairan dan Perikanan Indonesia, III(2), 41-50.

Nagahama, Y. (1995). Regulation of oocyte growth and maturation in fish. Development Biology, 30, 103-104.

Nagahama, Y., \& Yamashita, M. (2008). Regulation of 
oocyte maturation in fish. Develop. Growth Differ., 50, 196-291.

Rahmatia, F. (2013). Kajian kombinasi penambahan Spirulina platensis pada pakan dan penyuntikan Oodev terhadap kinerja produksi ikan nila. Tesis. Institut Pertanian Bogor. Bogor, $39 \mathrm{hlm}$.

Rachman, B. (2013). Manipulasi hormonal pada pematangan gonad ikan patin siam Pangasianodon hypopthalmus. Tesis. Institut Pertanian Bogor. Bogor, $42 \mathrm{hlm}$.

Rafiuddin, A. (2013). Karakterisasi, kloning dan rekayasa ekspresi gen FSH pada ikan patin selama awal perkembangan gonad. Tesis. Institut Pertanian Bogor. Bogor, $32 \mathrm{hlm}$.

Salerno, A.P., Marý' Ivi Dansa-Petretski, Ma' rio, A.C., Silva-Neto, Heloý'sa, S.L., Coelho, \& Atisaburo, M. (2002). Rhodnius prolixus vitellin is composed of three different populations: Comparison with vitellogenin. Insect Biochemistry and Molecular Biology, 32, 709-717.

Sargent, J.R., Tocher, D.R., \& Bell, J.G. (2002). Fish nutrition. Ed ke-3. Halver, J.E., Hardy, R.W. (Eds.). New York (US) Academic Press.

Tang, U.M., \& Affandy, R. (2000). Biologi reproduksi ikan. Pusat penelitian kawasan pantai dan perairan Universitas Riau. Pekanbaru, $110 \mathrm{hlm}$.

Thomas, P., \& Rahman, M.S. (2009). Biomarker of hypoxia exposure and reproductive function in Atlantic croaker: A review with some preliminary findings from northern gulf of Mexico hypoxic zone. Journal of Experimental Marine Biology and Ecology, 381, S38-S50.
Tyler, C. (1991). Viteollogenesis in salmonid. In Scott, A.P., Sumpter, J.P., Kime, D.E., \& Rolfe, M.S. (Eds.). Procedings of the Fourth International Symposium on the Reproductive Physiology of Fish. University of East Anglia. Norwich, p. 295-299.

Utiah, A. (2006). Penampilan reproduksi induk ikan baung (Hemibagrus nemurus Blkr) dengan pemberian pakan buatan yang ditambahkan asam lemak $n-6$ dan n-3 dan dengan implantasi estradiol-17 $\beta$ dan tiroksin. Disertasi. Institut Pertanian Bogor. Bogor, $86 \mathrm{hlm}$.

Watanabe, T.A., Arakawa, T., Kitajima, C., \& Fujita, S. (1984). Effect of nutritional quality of broodstock diets on reproduction of red sea bream. Nippon Suisan Gakkaishi, 50, 495-501.

www.totallab.com. 2013. Total Lab Ltd Keel House. Garth Heads. Newcastle upon Tyne. NE1 2JE. UK.

Xiao-ying, T., Zhi, L., Ping., \& Xiang-jiang, X. (2009). Effect of dietary linolenic acid/linoleic acid ratio on growth performance, hepatic fatty acid profiles and intermediary metabolism of juvenile yellow catfish Pelteobagrus fulvidraco. Aquaculture, 296, 96-101.

Zairin, M.Jr., Furukawa, K., \& Aida. (1992). Introduction of ovulation by hCG injection in tropical walking catfish Clarias gariepinus reared under 23ํ-25ㄷ․ Nippon Suisan Gakkashi, 58, 1681-1685.

Zairin, M.Jr., Furukawa, K., \& Aida, K. (2001). Induction of spawning in the tropical walking catfish, Clarias batracus by controling water level and temperature. Biotropia, 16, 18-27. 